\title{
The validation of the original and modified Caprini score in COVID-19 patients
}

\author{
Sergey Tsaplin ${ }^{1,2}$, Ilya Schastlivtsev ${ }^{1,2}$, Kirill Lobastov ${ }^{1}$, Sergey Zhuravlev ${ }^{2}$, Victor Barinov ${ }^{2}$, \\ Joseph A Caprini ${ }^{3}$
}

${ }^{1}$ Pirogov Russian National Research Medical University, Moscow, Russian Federation

${ }^{2}$ Clinical Hospital no.1 (Volynskaya) of the President's Administration of the Russian Federation, Moscow, Russian Federation

${ }^{3}$ University of Chicago Pritzker School of Medicine, Chicago, IL, USA

Corresponding author and the post-publication corresponding author: Kirill Lobastov, 117997, Ostrovitianov street build. 1, Department of General Surgery and Radiology, Moscow, Russian Federation, lobastov_kv@ hotmail.com

\section{ARTICLE HIGHLIGHTS}

Type of Research: A single-center retrospective analysis of prospectively collected data.

Key Findings: The original version of the Caprini score and its modifications considering the elevation of D-dimer and specific COVID-19 points demonstrated a significant association with symptomatic VTE and unfavorable outcome in 168 hospitalized COVID-19 patients, of whom $6.5 \%$ developed symptomatic VTE and $18.5 \%$ - unfavorable outcome despite routine pharmacoprophylaxis.

Take Home Message: The Caprini score allows stratification of COVID-19 inpatients according to their VTE risk and identification of subjects at extremely high risk. 


\section{TABLE OF CONTENTS SUMMARY}

This retrospective analysis of prospectively collected data demonstrates the significant association between the original and modified Caprini score and symptomatic VTE or unfavorable outcome in 168 patients with confirmed COVID-19. The Caprini score may be used for VTE risk assessment, and identification of persons at extremely high risk among COVID-19 patients admitted to the hospital.

\section{Abstract}

Objective. The study aimed to validate the original Caprini score and its modifications considering coronavirus disease (COVID-19) as a severe prothrombotic condition in patients admitted to the hospital with confirmed infection.

Methods. The relevant data were extracted from the electronic medical records with the implemented Caprini score and were evaluated retrospectively. The score was calculated twice: by the physician at the admission and by the investigator at discharge or after death. The second calculation at discharge, considered additional risk factors that occurred during inpatient treatment. Besides the original Caprini score (a version of 2005), the modified version added the elevation of D-dimer and specific scores for COVID-19 as follows: 2 points for asymptomatic, 3 points for symptomatic and 5 points for symptomatic infection with positive D-dimer, were evaluated in a retrospective manner. The primary endpoint was symptomatic venous thromboembolism (VTE) confirmed by appropriate imaging testing or dissection. The secondary endpoint included the unfavorable outcome as a combination of symptomatic VTE, admission to the intensive care unit, the requirement for invasive mechanical ventilation, and death. The association of eight different versions of the Caprini score with outcomes was evaluated. 
medRxiv preprint doi: https://doi.org/10.1101/2020.06.22.20137075; this version posted June 23, 2020. The copyright holder for this preprint (which was not certified by peer review) is the author/funder, who has granted medRxiv a license to display the preprint in perpetuity.

It is made available under a CC-BY-NC-ND 4.0 International license .

Results. Totally 168 patients ( 83 males and 85 females at the age of $58.3 \pm 12.7$ years old) were admitted to the hospital between April 30 and May 29, 2020, and were discharged or died up to the time of data analysis. The original Caprini score varied between 2-12

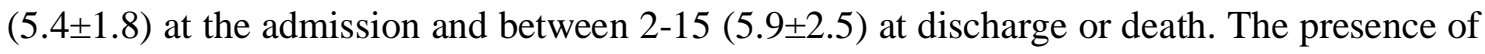
the virus increased these scores and resulted in an increased score with the maximal value for

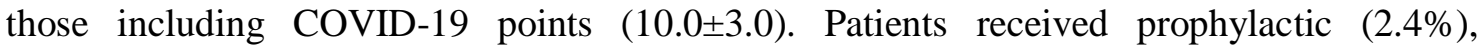
intermediate $(76.8 \%)$, or therapeutic $(20.8 \%)$ doses of enoxaparin. Despite this, the symptomatic VTE was detected in $11(6.5 \%)$ and unfavorable outcomes in $31(18.5 \%)$ patients. The Caprini score of all eight versions demonstrated a significant association with VTE with the highest predictability for the original scale when assessed at discharge. Supplementation of the original score by elevated D-dimer improved predictability only at the admission. Four versions of the Caprini score calculated at the admission had a significant correlation with the unfavorable outcome with the minor advantages of specific COVID-19 points.

Conclusion. The study identified a significant correlation between the Caprini score and the risk of VTE or unfavorable outcomes in COVID-19 patients. All models, including specific COVID-19 scores, showed high predictability with minor differences.

Keywords: COVID-19, venous thromboembolism, risk assessment, caprini score, prophylaxis 


\section{Introduction}

Coronavirus disease (COVID-19) is a highly infectious disease caused by the SARS$\mathrm{CoV}-2$ virus leading to the development of severe pneumonia and acute respiratory distress syndrome (ARDS). The infection has appeared in Wuhan, Hubei Province, China, in December of 2019, and has been spread globally. ${ }^{1}$ The high prevalence of venous thromboembolism (VTE), including deep vein thrombosis (DVT), pulmonary embolism (PE), and pulmonary artery (PA) thrombosis, among the inpatients and critically ill patients, have been reported since the beginning of the pandemic. ${ }^{2-11}$ The overall duplex ultrasound scan (DUS) detected the presence of DVT in $46 \%$ of the patients in the general ward and up to $79 \%$ of the patients in the intensive care unit (ICU). ${ }^{10,11}$ Proven PE using contrast computed tomography (CT) scan was observed in $30 \%$ of all COVID-19 patients. $^{8}$ The evidence of small and mid-sized PA thrombosis and microthrombi in alveolar capillaries was found in most of the deceased patients in parallel with the occlusion of big branches of PA in 9-33\% of dissections. ${ }^{12-16}$ Considering the high incidence of thrombotic complications in COVID-19, most of the current guidelines suggest routine pahrmacoprophylaxis using low-molecularweight heparin (LMWH) or unfractionated heparin (UFH) for patients admitted to the hospital. ${ }^{17-21}$ Some publications support the intensification of anticoagulation (intermediate to therapeutic doses of heparin) in subjects at individually highest risk for VTE including critical illness, obesity, and high level of D-dimer. ${ }^{17,} 19,20$ The tools mentioned in these publications for VTE risk assessment include: the Caprini score, Padua score, and IMPROVE VTE score. ${ }^{18-20}$ The Padua score was assessed in two papers without a clear correlation with

VTE events. ${ }^{22,23}$ To the best of our knowledge, the Caprini and IMPROVE VTE scores have not been validated in COVID-19 patients. 
medRxiv preprint doi: https://doi.org/10.1101/2020.06.22.20137075; this version posted June 23, 2020. The copyright holder for this preprint (which was not certified by peer review) is the author/funder, who has granted medRxiv a license to display the preprint in perpetuity.

It is made available under a CC-BY-NC-ND 4.0 International license .

To cover this gap, we decided to perform the current study aimed to validate the original Caprini score and its modified version considering COVID-19 as a severe prothrombotic condition in patients admitted to the hospital with confirmed SARS-CoV-2 infection. We also tested the influence of several levels of D-dimer combined with the original Caprini score to improve the identification of patients at the highest risk of VTE.

\section{Methods}

This study is a single-center retrospective analysis of prospectively collected data obtained from medical records of patients admitted at the Clinical Hospital no.1 (Volynskaya) of the President's Administration of the Russian Federation (Moscow, Russian Federation) with verified COVID-19. The hospital stopped standard medical care and was reoriented for COVID-19 on April 30, 2020. Two years before the Caprini score (a version of 2005 in Russian translation ${ }^{24}$ ) was integrated into the electronic medical records (EMR) and became mandatory for assessment. The EMRs were extracted on May 30, 2020, when all COVID-19 patients were discharged, and the hospital turned back to the standard care.

The initial Caprini score was calculated by the physician at the time of patients admission. It did not take into account some risk factors related to inpatient treatment (bed rest for $>72$ hours, central venous catheter, acquired thrombophilia, etc.). Standard coagulation testing, including the level of D-dimer, prothrombin time (PT), activated partial thromboplastin time (APTT), was performed in all admitted patients but was not considered within the primary assessment of Caprini score. The reason being at the time of admission, the blood test results were not known by the initial examiner. In Russia, the indication for inpatient treatment for adults is a moderate to severe disease according to the locally adopted criteria with respiratory rate $>22$ per min or $\mathrm{SpO}_{2}<93 \%$ with room air, a mild illness in subjects over 65 years old with significant co-morbidities (chronic heart failure, diabetes mellitus, chronic obstructive pulmonary disease [COPD]), and pregnancy. We decided that 
medRxiv preprint doi: https://doi.org/10.1101/2020.06.22.20137075; this version posted June 23, 2020. The copyright holder for this preprint

all patients with moderate to severe illness and/or representing specific signs of pneumonia on a chest CT scan should receive one Caprini point for pneumonia at the admission as well as one additional score for medical illness with bed rest (Table I).

The final score was assessed by the two investigators via EMR after patients' discharge or death. The additional risk factors related to inpatient treatment were evaluated. Also, the elevated D-dimer at admission was assessed as "acquired" thrombophilia from the block of 3 scores. We used a liberal or strict approach in the assessment of D-dimer and achieved two different versions of the Caprini score. In the liberal version, we put an additional 3 points for any patient who had elevated D-dimer over the upper limit of normal (ULN: $>0,55 \mathrm{mg} / \mathrm{L})$ at the admission. Within the strict version, only patients with D-dimer $>3$ times ULN $(>1,5$ $\mathrm{mg} / \mathrm{L}$ ) received the additional 3 points. Due to the coronavirus pandemic, one of the authors (JA Caprini) proposed using a modified score for COVID-19 patients. It adds 2 points for COVID-19 patients with asymptomatic disease, 3 points for those with symptomatic illness, and 5 points for symptomatic patients with a positive D-dimer. This modification also was used for the retrospective analysis.

We calculated the four different Caprini scores obtained at the admission and the discharge or death. We achieved eight versions of the scale: Caprini[orig:adm] - original score calculated at admission; Caprini[orig:fin] - original score calculated at discharge or death; Caprini[Dd>ULN:adm] - score with liberal D-dimer calculated at admission; Caprini[Dd>ULN:fin] - score with liberal D-dimer calculated at discharge or death; Caprini[Dd>3ULN:adm] - score with strict D-dimer calculated at admission; Caprini[Dd>3ULN:fin] - score with strict D-dimer calculated at discharge or death; Caprini[COVID-19:adm] - modified score calculated at admission; Caprini[COVID-19:fin] modified score calculated at discharge or death. 
medRxiv preprint doi: https://doi.org/10.1101/2020.06.22.20137075; this version posted June 23, 2020. The copyright holder for this preprint (which was not certified by peer review) is the author/funder, who has granted medRxiv a license to display the preprint in perpetuity.

It is made available under a CC-BY-NC-ND 4.0 International license .

The standard prevention of VTE included prophylactic or intermediate doses of LMWH. The local protocol proposed in our clinic required intermediate doses of LMWH for all patients without bleeding risk. It was suggested at the background of the high prevalence of VTE and PA thrombosis in COVID-19 patients. Although not all international guidelines support this approach, it was not contradictory to the interim Russian national recommendations. Only patients at high risk of bleeding were managed with the standard prophylactic doses LMWH. The therapeutic anticoagulation was prescribed for subjects without confirmed VTE in case of a critical level of D-dimer ( $>6$ times the ULN) or suspected thrombi in PA (e.g., hypoxemia disproportionate to known respiratory pathologies, or acute unexplained right ventricular dysfunction). The local protocol suggested empiric initiation of therapeutic anticoagulation in case of presumptive VTE with the mandatory further verification by appropriate imaging tests before discharge. A duplex ultrasound scan was used to assess superficial and deep veins of lower and upper extremities, computed tomography pulmonary angiogram (CTPA) - to exclude thrombi in the pulmonary artery. If the patient died, the autopsy with an evaluation of lung vessels and veins of lower limbs was obligatory for the final VTE verification.

The primary endpoint was symptomatic venous thromboembolism confirmed by appropriate imaging testing or dissection at autopsy. The secondary endpoints included: (1) the unfavorable outcome as a combination of symptomatic VTE, admission to the ICU, the requirement for invasive mechanical ventilation, and death, and (2) a bleeding outcome as a combination of major and clinically relevant non-major (CRNM) bleeding by the criteria of International Society of Thrombosis and Hemostasis. ${ }^{25,26}$ All events were assessed in a retrospective manner by three experienced in vascular surgery investigators, according to the data extracted from EMRs. The correlation with the VTE event was evaluated for the Caprini 
medRxiv preprint doi: https://doi.org/10.1101/2020.06.22.20137075; this version posted June 23, 2020. The copyright holder for this preprint (which was not certified by peer review) is the author/funder, who has granted medRxiv a license to display the preprint in perpetuity.

It is made available under a CC-BY-NC-ND 4.0 International license .

score calculated either at admission or discharge or death. In contrast, the correlation between an unfavorable outcome and the Caprini score was done only at the time of admission.

No need for ethical approval and a waiver of informed consent because of the retrospective character of the analysis in the urgent situation was confirmed by the Institutional Review Board of Clinical Hospital no.1 of the President's Administration of the Russian Federation.

Statistical analysis. All absolute values are represented by mean with standard deviation (SD) in the normal distribution or by a median with interquartile range (IQR) 25-75 percentile in the non-normal distribution assessed by Kolmogorov-Smirnov test. The relative values are represented as percents, with a 95\% confidence interval (CI) calculated by Wilson. The data were compared by paired t-test or ANOVA. The association between the Caprini score and outcomes was evaluated by the generalized linear model (GLM), a form of linear regression analysis. The predictability of Caprini scores for proposed outcomes was assessed by a single-factor univariate logistic regression analysis and evaluation of receiver operating characteristic (ROC) curves with their areas under the curve (AUC). The cut-off for the Caprini score with current sensitivity and specificity was extracted from the coordinates of ROC curves. The analysis was performed using SPSS version 26 software package (IBM Corp, Armonk, NY). The value of $\mathrm{p}<0.05$ was considered statistically significant.

\section{Results}

A total of 168 patients were admitted to the hospital between April 30 and May 29, 2020. Up to the time of data extraction, everybody was discharged or died, and every EMR was eligible for analysis. The number of males and females was equivalent (83 and 85, respectively). The age varied between 21 and 86 (mean of 58.3 \pm 12.7 ) years old. COVID-19 diagnosis was confirmed with polymerase chain reaction on nasopharyngeal swabs of 140 patients (83\%); $28(17 \%)$ despite the negative result had a typical pattern of viral pneumonia 
medRxiv preprint doi: https://doi.org/10.1101/2020.06.22.20137075; this version posted June 23, 2020. The copyright holder for this preprint (which was not certified by peer review) is the author/funder, who has granted medRxiv a license to display the preprint in perpetuity.

It is made available under a CC-BY-NC-ND 4.0 International license .

on chest CT scan (ground-glass opacity) as assessed by the experienced radiologists. The interim Russian national guidelines classified the disease severity as moderate (body temperature $>38$ degrees of Celsium, respiratory rate $>22$ per min, dyspnea in physical activity, pneumonia by chest CT scan, $\mathrm{SpO}_{2}<95 \%$, C-reactive protein $>10 \mathrm{mg} / \mathrm{mL}$ ) in 155 $(92 \%)$ patients. Severe disease criteria (respiratory rate $>30$ per min, $\mathrm{SpO}_{2} \leq 93 \%, \mathrm{PaO}_{2} / \mathrm{FiO}_{2}$ $\leq 300 \mathrm{~mm} \mathrm{Hg}$, disease progression by chest CT scan, a decrease of consciousness or agitation, unstable hemodynamics, serum lactate $>2 \mathrm{mmol} / \mathrm{L}$, qSOFA >2) were found in $13(8 \%)$ subjects. Time to admission from the onset of symptoms varied between 1 and 24 (mean of 7.2 \pm 4.0 ) days. During this period, patients were treated at home with symptomatic therapy, chloroquine or hydroxychloroquine, and antibiotics.

The PT at the admission ranged from 9.3 to $29.1 \mathrm{sec}$ (mean of $11.6 \pm 1.9 \mathrm{sec}$; the normal range of 9.8-12.1 sec). It was prolonged in nine (5\%) patients. The APTT varied between 22.0-54.1 sec (mean of 32.9 $\pm 5.0 \mathrm{sec}$; the normal range of $26.4-37.5 \mathrm{sec}$ ). It was increased in $44(26 \%)$ subjects. The D-dimer varied from 0,1 to $6.7 \mathrm{mg} / \mathrm{L}$ (median of $0.6 \mathrm{mg} / \mathrm{L}$ with the IQR of $0.4-1.0 \mathrm{mg} / \mathrm{L}$; ULN is $0.55 \mathrm{mg} / \mathrm{L}$ ). Any elevation of D-dimer was observed in 102 (61\%) patients and elevation >3 times ULN - in 15 (9\%) subjects. We did not use the ageadjusted ULN for D-dimer like all previous reports on its level in patients with COVID-19., $8,10,27-34$

All patients received therapy with chloroquine or hydroxychloroquine, antibiotics, noninvasive and invasive oxygen therapy, symptomatic treatment, and prophylactic anticoagulation. The LMWH was used in the standard prophylactic dose (enoxaparin $40 \mathrm{mg}$ once daily) in 4 (2.4\%) patients, in the intermediate dose (enoxaparin 60-80 $\mathrm{mg}$ once daily) in $129(76.8 \%)$ patients, and in therapeutic doses (enoxaparin $1 \mathrm{mg} / \mathrm{kg}$ twice daily) in 35 (20.8\%) patients. The duration of inpatient treatment varied from 1 to 29 days (mean of $13.9 \pm 4.0$ days $)$. 
medRxiv preprint doi: https://doi.org/10.1101/2020.06.22.20137075; this version posted June 23, 2020. The copyright holder for this preprint (which was not certified by peer review) is the author/funder, who has granted medRxiv a license to display the preprint in perpetuity.

It is made available under a CC-BY-NC-ND 4.0 International license .

The risk factor distribution by the Caprini score is represented in Table I. By the original scale, the score ranged from 2 to 12 (mean of 5.4 \pm 1.8 ) as calculated at the admission and between 2 and 15 (mean of 5.9 \pm 2.5 ) as calculated at discharge or death. Among all modifications, the highest score was observed with Caprini[COVID-19] version followed by Caprini[Dd $>\mathrm{ULN}]$, Caprini[Dd $>3 \mathrm{ULN}]$, and the original version. All scores significantly increased when they were measured at the end of hospitalization (Table II).

The symptomatic VTE was detected in 11 of 168 (6.5\%; 95\% CI, 3.7-11.3\%) patients including catheter-related venous thrombosis of upper limbs in 3 (1.8\%; 95\% CI, 0.6-5.1\%) cases; isolated DVT in $2(1.2 \%$; $95 \%$ CI, $0.3-4.3 \%)$ cases; combination of DVT and PE in 1 (0.6\%; $95 \% \mathrm{CI}, 0.1-3.3 \%)$ case, and isolated PE in $5(3.0 \%$; $95 \% \mathrm{CI}, 1.3-6.8 \%)$ cases. Of three DVT, two affected the distal veins, and one - the proximal veins. Thrombosis of calf muscle veins was the only one of these leg clots associated with PE. Of six pulmonary embolism, five were fatal and confirmed by autopsy; the last one was confirmed by CTPA. All lesions affected segmental and subsegmental branches of PA. All VTE events developed despite intermediate $(n=5)$ or therapeutic $(n=6)$ doses of LMWH.

The unfavorable outcome was detected in 31 (18.5\%; 95\% CI, 13.1-24.7\%) patients including admission to the ICU in 28 (16.7\%; 95\% CI, 11.8-23.1\%), the requirement for mechanical ventilation in $8(4.8 \%$; $95 \%$ CI, $2.5-9.2 \%)$, and death in 8 (4.8\%; 95\% CI, 2.5 $9.2 \%$ ) cases. Of 8 patients on mechanical ventilation, 7 (88\%) finally died. The CRNM bleeding was detected in only $2(1.2 \% ; 95 \%$ CI, $0.3-4.3 \%)$ subjects represented by subcutaneous hematoma required surgical drainage and uterine bleeding. Both occurred while receiving a therapeutic and intermediate dose of $\mathrm{LMWH}$, respectively.

The statistically significant association with symptomatic VTE was observed for all versions of the Caprini score calculated either at the admission or discharge or death $(\mathrm{p}<0.001$, Figures 1 and 2$)$. The high predictability was confirmed by the single-factor 
medRxiv preprint doi: https://doi.org/10.1101/2020.06.22.20137075; this version posted June 23, 2020. The copyright holder for this preprint (which was not certified by peer review) is the author/funder, who has granted medRxiv a license to display the preprint in perpetuity.

It is made available under a CC-BY-NC-ND 4.0 International license .

logistic regression analysis (Table III) and the analysis of ROC curves (Table IV, Figure 4). Among the scores calculated at the admission, the highest predictability by the area under the curve was found for the version considering any elevation of D-dimer (Caprini[Dd>ULN:adm]). The score of $\geq 10$ with the sensitivity of $73 \%$ and specificity of $85 \%$ predicted the occurrence of symptomatic venous thromboembolism. However, the standard version (Caprini[orig:adm]) demonstrated high predictability as well: with a sensitivity of $73 \%$ and the specificity of $80 \%$, the score of $\geq 7$ predicted VTE. Among those scores obtained at the discharge or death, the best predictability was observed for the original version of the scale (Caprini[orig:fin]): with the sensitivity of $73 \%$ and specificity of $96 \%$ score of $\geq 11$ predicted VTE. Also, this model had the highest AUC among all evaluated. The second highest predictability was observed for the version considering any elevation of Ddimer (Caprini[Dd>ULN:fin]): with the sensitivity of $73 \%$ and specificity of $97 \%$ score of $\geq 14$ predicted VTE. Generally, better predictability and higher specificity were observed for the Caprini score obtained at the end of inpatient treatment.

The significant association between the Caprini score of all versions obtained at the admission and the unfavorable outcome in COVID-19 patients was observed (Figure 3). The logistic regression and the analysis of ROC curves confirmed the high predictability of all models (Table III, IV, Figure 5). The modified version considering the COVID-19 points (Caprini[COVID-19:adm]) provided the highest AUC. The score of $\geq 11$ with the sensitivity of $68 \%$ and specificity of $75 \%$ predicted the unfavorable outcome. However, the original version (Caprini[orig:adm]) provided comparable predictability: the score of $\geq 6$ predicted the unfavorable outcome with the sensitivity of $74 \%$ and specificity of $66 \%$.

\section{Discussion}

The Caprini score is the most validated risk assessment tool for VTE that was evaluated in about 5 million medical and surgical patients worldwide. ${ }^{35-37}$ The previous study showed 
medRxiv preprint doi: https://doi.org/10.1101/2020.06.22.20137075; this version posted June 23, 2020. The copyright holder for this preprint (which was not certified by peer review) is the author/funder, who has granted medRxiv a license to display the preprint in perpetuity.

It is made available under a CC-BY-NC-ND 4.0 International license .

improved predictability when the results of viscoelastic measurements supplemented the original score. ${ }^{38}$ However, it has not been validated in patients infected by SARS-CoV-2 to date. Despite this, the American Venous Forum has already recommended using the Caprini score for VTE risk assessment at admission and discharge. ${ }^{19}$ They referenced the original Caprini score in their recommendations. The score of $\geq 8$ was suggested as an indication for the intensification of pharmacological prophylaxis in the hospital and extended prophylaxis after discharge. Our study is the first to use a COVID-19 modified Caprini score, and compare it to the original score. We also tested some theoretical score modifications based on the D-dimer level. At the same time, our study shows that an original score of $\geq 7$, as calculated at admission, and a score of $\geq 11$, as calculated at discharge, are associated with increased risk of VTE despite the administration of LMWH (predominantly intermediate doses). Such patients may be considered as an extremely high-risk group that requires special attention. The threshold of 11 points has been identified previously as a criterion for extremely high-risk of VTE in surgical patients. ${ }^{24,38}$ The importance of the D-dimer level in COVID-19 was introduced recently. It appears to be associated with unfavorable outcomes, increased mortality, and VTE. 3, 8, 10, 27-34 The thresholds for VTE verification were found at the levels of $1.0-2.3 \mathrm{mg} / \mathrm{L}^{3,8,10}$. The prophylactic doses of $\mathrm{LMWH}$ increased survival in patients with D-dimer level $>6$ times the ULN. ${ }^{39}$ The American Venous Forum proposed therapeutic anticoagulation for subjects with D-dimer $>3$ times ULN. ${ }^{19}$ However, in our study, the suggested level of D-dimer supplemented the scale did not improve the predictability of the original Caprini score for VTE. At the same time, considering any elevation of D-dimer improved the predictability and specificity of the original score when calculated at admission, but not at the discharge. In general, all evaluated models demonstrated good predictability with minor differences. 
medRxiv preprint doi: https://doi.org/10.1101/2020.06.22.20137075; this version posted June 23, 2020. The copyright holder for this preprint (which was not certified by peer review) is the author/funder, who has granted medRxiv a license to display the preprint in perpetuity.

It is made available under a CC-BY-NC-ND 4.0 International license .

The predictive value for the unfavorable outcome was similar for all models with limited advantage of the one considering the new COVID-19 points. It was the only issue where the suggested modification appeared useful. However, the original version demonstrated sufficient predictability. Of note, any change of the original Caprini score affects the predictive threshold for extremely high-risk group, which could vary by 4-5 points. So the prognosis for VTE and detection of patients requiring intensified prophylaxis and/or additional imagining tests for VTE should be based on a specific threshold of every version of the scale (Table IV).

Interestingly, the incidence of VTE and mortality rate in our study appeared to be lower than previously reported for the general ward., 7, 10 This fact may be related to the use of intermediate to therapeutic doses of LMWH in $97,6 \%$ of all patients. There is a limited evidence that therapeutic anticoagulation can improve survival in COVID-19 patients requiring mechanical ventilation. ${ }^{40}$ However, the risk-benefit ratio of intensified anticoagulation should be confirmed in robust randomized clinical trials.

The study was limited by a retrospective character, small sample size, absence of the total instrumental screening for VTE, and lack of follow-up after discharge. Despite these disadvantages, it may be essential to improve VTE risk stratification in COVID-19 patients.

\section{Conclusion}

The study identified a direct correlation between the Caprini score and the risk of VTE or unfavorable outcomes in COVID-19 patients. The score of $\geq 7$, as calculated at the admission, or $\geq 11$, as evaluated at the discharge, predicts symptomatic venous thromboembolism despite pharmacological prophylaxis. The predictability of the original score may be improved by the implementation of a D-dimer or specific COVID-19 points. However, the original Caprini score is essential. Further studies are needed to determine if there are any clinical benefits using the modified COVID-19 Caprini score. It will be 
medRxiv preprint doi: https://doi.org/10.1101/2020.06.22.20137075; this version posted June 23, 2020. The copyright holder for this preprint (which was not certified by peer review) is the author/funder, who has granted medRxiv a license to display the preprint in perpetuity.

It is made available under a CC-BY-NC-ND 4.0 International license .

especially important to track 90-day clinical events based both on the discharge modified Caprini score and the use of post-discharge prophylaxis.

\section{References}

1. Zhu N, Zhang D, Wang W, Li X, Yang B, Song J, et al. A Novel Coronavirus from Patients with Pneumonia in China, 2019. N Engl J Med. 2020;382(8):727-33.

2. Xu Z, Shi L, Wang Y, Zhang J, Huang L, Zhang C, et al. Pathological findings of COVID-19 associated with acute respiratory distress syndrome. Lancet Respir Med. 2020;8(4):420-2.

3. Cui S, Chen S, Li X, Liu S, Wang F. Prevalence of venous thromboembolism in patients with severe novel coronavirus pneumonia. J Thromb Haemost. 2020;n/a(n/a).

4. Lodigiani C, Iapichino G, Carenzo L, Cecconi M, Ferrazzi P, Sebastian T, et al. Venous and arterial thromboembolic complications in COVID-19 patients admitted to an academic hospital in Milan, Italy. Thromb Res. 2020;191:9-14.

5. Klok FA, Kruip MJHA, van der Meer NJM, Arbous MS, Gommers DAMPJ, Kant $\mathrm{KM}$, et al. Incidence of thrombotic complications in critically ill ICU patients with COVID19. Thromb Res. 2020;191:145-7.

6. Helms J, Tacquard C, Severac F, Leonard-Lorant I, Ohana M, Delabranche X, et al. High risk of thrombosis in patients with severe SARS-CoV-2 infection: a multicenter prospective cohort study. Intensive Care Med. 2020.

7. Middeldorp S, Coppens M, van Haaps TF, Foppen M, Vlaar AP, Müller MCA, et al. Incidence of venous thromboembolism in hospitalized patients with COVID-19. Journal of Thrombosis and Haemostasis. 2020;n/a(n/a).

8. Leonard-Lorant I, Delabranche X, Severac F, Helms J, Pauzet C, Collange O, et al. Acute Pulmonary Embolism in COVID-19 Patients on CT Angiography and Relationship to D-Dimer Levels. Radiology. 2020:201561.

9. Poissy J, Goutay J, Caplan M, Parmentier E, Duburcq T, Lassalle F, et al. Pulmonary Embolism in COVID-19 Patients: Awareness of an Increased Prevalence. Circulation. 2020;0(0).

10. Zhang L, Feng X, Zhang D, Jiang C, Mei H, Wang J, et al. Deep Vein Thrombosis in Hospitalized Patients with Coronavirus Disease 2019 (COVID-19) in Wuhan, China: Prevalence, Risk Factors, and Outcome. Circulation. 2020;0(0). 
medRxiv preprint doi: https://doi.org/10.1101/2020.06.22.20137075; this version posted June 23, 2020. The copyright holder for this preprint (which was not certified by peer review) is the author/funder, who has granted medRxiv a license to display the preprint in perpetuity.

It is made available under a CC-BY-NC-ND 4.0 International license .

11. Nahum J, Morichau-Beauchant T, Daviaud F, Echegut P, Fichet J, Maillet J-M, et al. Venous Thrombosis Among Critically Ill Patients With Coronavirus Disease 2019 (COVID19). JAMA Network Open. 2020;3(5):e2010478-e.

12. Lax SF, Skok K, Zechner P, Kessler HH, Kaufmann N, Koelblinger C, et al. Pulmonary Arterial Thrombosis in COVID-19 With Fatal Outcome: Results From a Prospective, Single-Center, Clinicopathologic Case Series. Ann Intern Med. 2020.

13. Carsana L, Sonzogni A, Nasr A, Rossi R, Pellegrinelli A, Zerbi P, et al. Pulmonary post-mortem findings in a large series of COVID-19 cases from Northern Italy. medRxiv. 2020:2020.04.19.20054262.

14. Menter T, Haslbauer JD, Nienhold R, Savic S, Hopfer H, Deigendesch N, et al. Postmortem examination of COVID19 patients reveals diffuse alveolar damage with severe capillary congestion and variegated findings of lungs and other organs suggesting vascular dysfunction. Histopathology. 2020;n/a(n/a).

15. Wichmann D, Sperhake JP, Lutgehetmann M, Steurer S, Edler C, Heinemann A, et al. Autopsy Findings and Venous Thromboembolism in Patients With COVID-19. Ann Intern Med. 2020.

16. Fox SE, Akmatbekov A, Harbert JL, Li G, Quincy Brown J, Vander Heide RS. Pulmonary and cardiac pathology in African American patients with COVID-19: an autopsy series from New Orleans. The Lancet Respiratory Medicine. 2020.

17. Spyropoulos AC, Levy JH, Ageno W, Connors JM, Hunt BJ, Iba T, et al. Scientific and Standardization Committee Communication: Clinical Guidance on the Diagnosis, Prevention and Treatment of Venous Thromboembolism in Hospitalized Patients with COVID-19. Journal of Thrombosis and Haemostasis. 2020;n/a(n/a).

18. Bikdeli B, Madhavan MV, Jimenez D, Chuich T, Dreyfus I, Driggin E, et al. COVID19 and Thrombotic or Thromboembolic Disease: Implications for Prevention, Antithrombotic Therapy, and Follow-up. J Am Coll Cardiol. 2020.

19. The COVID-19 Sub-Committee of the American Venous Forum. Considerations in prophylaxis and treatment of VTE in COVID-19 Patients. 2020 [cited 2020 29.05.]; Available from: https://www.veinforum.org/wp-content/uploads/2020/04/COVID-19-WhitePaper-04-17-2020-FINAL-1.pdf.

20. Oudkerk M, Buller HR, Kuijpers D, van Es N, Oudkerk SF, McLoud TC, et al. Diagnosis, Prevention, and Treatment of Thromboembolic Complications in COVID-19: Report of the National Institute for Public Health of the Netherlands. Radiology. 2020:201629. 
medRxiv preprint doi: https://doi.org/10.1101/2020.06.22.20137075; this version posted June 23, 2020. The copyright holder for this preprint (which was not certified by peer review) is the author/funder, who has granted medRxiv a license to display the preprint in perpetuity.

It is made available under a CC-BY-NC-ND 4.0 International license .

21. National Institutes of Health. COVID-19 Treatment Guidelines Panel. Coronavirus Disease 2019 (COVID-19) Treatment Guidelines. 2020 [cited 2020 29.05.]; Available from: https://www.covid19treatmentguidelines.nih.gov/.

22. Xu J-f, Wang L, Zhao L, Li F, Liu J, Zhang L, et al. Risk assessment of venous thromboembolism and bleeding in COVID-19 patients. Respiratory Research. 2020.

23. Wang T, Chen R, Liu C, Liang W, Guan W, Tang R, et al. attention should be paid to venous thromboembolism prophylaxis in the management of COVID-19. The Lancet Haematology. 2020;7(5):e362-e3.

24. Lobastov K, Barinov V, Schastlivtsev I, Laberko L, Rodoman G, Boyarintsev V. Validation of the Caprini risk assessment model for venous thromboembolism in high-risk surgical patients in the background of standard prophylaxis. Journal of Vascular Surgery: Venous and Lymphatic Disorders. 2016;4(2):153-60.

25. Kaatz S, Ahmad D, Spyropoulos AC, Schulman S, Subcommittee on Control of Anticoagulation. Definition of clinically relevant non-major bleeding in studies of anticoagulants in atrial fibrillation and venous thromboembolic disease in non-surgical patients: communication from the SSC of the ISTH. J Thromb Haemost. 2015;13(11):211926.

26. Schulman S, Angeras U, Bergqvist D, Eriksson B, Lassen MR, Fisher W, et al. Definition of major bleeding in clinical investigations of antihemostatic medicinal products in surgical patients. J Thromb Haemost. 2010;8(1):202-4.

27. Han H, Yang L, Liu R, Liu F, Wu KL, Li J, et al. Prominent changes in blood coagulation of patients with SARS-CoV-2 infection. Clin Chem Lab Med. 2020.

28. Gao Y, Li T, Han M, Li X, Wu D, Xu Y, et al. Diagnostic utility of clinical laboratory data determinations for patients with the severe COVID-19. J Med Virol. 2020.

29. Huang C, Wang Y, Li X, Ren L, Zhao J, Hu Y, et al. Clinical features of patients infected with 2019 novel coronavirus in Wuhan, China. Lancet. 2020;395(10223):497-506.

30. Wang D, Hu B, Hu C, Zhu F, Liu X, Zhang J, et al. Clinical Characteristics of 138 Hospitalized Patients With 2019 Novel Coronavirus-Infected Pneumonia in Wuhan, China. Jama. 2020;323(11):1061-9.

31. Zhou F, Yu T, Du R, Fan G, Liu Y, Liu Z, et al. Clinical course and risk factors for mortality of adult inpatients with COVID-19 in Wuhan, China: a retrospective cohort study. Lancet. 2020;395(10229):1054-62. 
medRxiv preprint doi: https://doi.org/10.1101/2020.06.22.20137075; this version posted June 23, 2020. The copyright holder for this preprint (which was not certified by peer review) is the author/funder, who has granted medRxiv a license to display the preprint in perpetuity.

It is made available under a CC-BY-NC-ND 4.0 International license .

32. Wu C, Chen X, Cai Y, Xia J, Zhou X, Xu S, et al. Risk Factors Associated With Acute Respiratory Distress Syndrome and Death in Patients With Coronavirus Disease 2019 Pneumonia in Wuhan, China. JAMA Intern Med. 2020.

33. Tang N, Li D, Wang X, Sun Z. Abnormal coagulation parameters are associated with poor prognosis in patients with novel coronavirus pneumonia. J Thromb Haemost. 2020;18(4):844-7.

34. Wang Y, Lu X, Chen H, Chen T, Su N, Huang F, et al. Clinical Course and Outcomes of 344 Intensive Care Patients with COVID-19. Am J Respir Crit Care Med. 2020;0(ja):null.

35. Grant PJ, Greene MT, Chopra V, Bernstein SJ, Hofer TP, Flanders SA. Assessing the Caprini Score for Risk Assessment of Venous Thromboembolism in Hospitalized Medical Patients. Am J Med. 2016;129(5):528-35.

36. Pannucci CJ, Swistun L, MacDonald JK, Henke PK, Brooke BS. Individualized Venous Thromboembolism Risk Stratification Using the 2005 Caprini Score to Identify the Benefits and Harms of Chemoprophylaxis in Surgical Patients: A Meta-analysis. Ann Surg. 2017;265(6):1094-103.

37. Hanh BM, Cuong LQ, Son NT, Duc DT, Hung TT, Hung DD, et al. Determination of Risk Factors for Venous Thromboembolism by an Adapted Caprini Scoring System in Surgical Patients. J Pers Med. 2019;9(3).

38. Lobastov K, Dementieva G, Soshitova N, Bargandzhiya A, Barinov V, Laberko L, et al. Utilization of the Caprini score in conjunction with thrombodynamic testing reduces the number of unpredicted postoperative venous thromboembolism events in patients with colorectal cancer. J Vasc Surg Venous Lymphat Disord. 2020;8(1):31-41.

39. Tang N, Bai H, Chen X, Gong J, Li D, Sun Z. Anticoagulant treatment is associated with decreased mortality in severe coronavirus disease 2019 patients with coagulopathy. Journal of Thrombosis and Haemostasis. 2020;18(5):1094-9.

40. Paranjpe I, Fuster V, Lala A, Russak A, Glicksberg BS, Levin MA, et al. Association of Treatment Dose Anticoagulation with In-Hospital Survival Among Hospitalized Patients with COVID-19. J Am Coll Cardiol. 2020. 
Table I. The distribution of the individual risk factors for VTE according to the Caprini score

\begin{tabular}{|c|c|c|}
\hline Risk factor & Score & $\begin{array}{l}\text { Number of } \\
\text { patients }(\%)\end{array}$ \\
\hline Age 41-60 years & 1 & $75(45 \%)$ \\
\hline Swollen legs & 1 & $32(19 \%)$ \\
\hline Varicose veins & 1 & $32(19 \%)$ \\
\hline Obesity (BMI >25) & 1 & $131(78 \%)$ \\
\hline Minor surgery & 1 & $0(0 \%)$ \\
\hline Sepsis (<1 month) & 1 & $72(43 \%)$ \\
\hline Acute miocardial infarction & 1 & $0(0 \%)$ \\
\hline Congestive heart failure ( $<1$ month $)$ & 1 & $24(14 \%)$ \\
\hline Medical patient currently at bed rest & 1 & $168(100 \%)$ \\
\hline History of inflammatory bowel disease & 1 & $4(2 \%)$ \\
\hline History of prior major surgery ( $<1$ month $)$ & 1 & $0(0.0 \%)$ \\
\hline Abnormal pulmonary function (COPD) & 1 & $8(5 \%)$ \\
\hline Serious ling disease including pneumonia ( $<1$ month) & 1 & $168(100 \%)$ \\
\hline Oral contraceptives or hormone replacement therapy & 1 & $0(0 \%)$ \\
\hline Pregnancy or postpartum (<1 month) & 1 & $0(0 \%)$ \\
\hline $\begin{array}{l}\text { History of unexplained stillborn infant, recurrent spontaneous } \\
\text { abortion ( } \geq 3) \text {, premature birth with toxemia or growth-restricted } \\
\text { infant }\end{array}$ & 1 & $1(0.6 \%)$ \\
\hline Age $61-74$ years & 2 & $61(36 \%)$ \\
\hline Central venous access ${ }^{\dagger}$ & 2 & $22(13 \%)$ \\
\hline Arthroscopic surgery & 2 & $0(0 \%)$ \\
\hline Major surgery (>45 min) & 2 & $0(0 \%)$ \\
\hline Malignancy (present or previous) & 2 & $0(0 \%)$ \\
\hline Laparoscopic surgery (>45 min) & 2 & $0(0 \%)$ \\
\hline Patient confined to bed (>72 hours) ${ }^{\dagger}$ & 2 & $14(8 \%)$ \\
\hline Immobilizing plaster cast ( $<1$ month) & 2 & $0(0 \%)$ \\
\hline COVID-19 asymptomatic ${ }^{\square}$ & 2 & $0(0 \%)$ \\
\hline Age 75 years or older & 3 & $19(11 \%)$ \\
\hline History of DVT/PE & 3 & $6(4 \%)$ \\
\hline
\end{tabular}


medRxiv preprint doi: https://doi.org/10.1101/2020.06.22.20137075; this version posted June 23, 2020. The copyright holder for this preprint (which was not certified by peer review) is the author/funder, who has granted medRxiv a license to display the preprint in perpetuity.

It is made available under a CC-BY-NC-ND 4.0 International license .

\begin{tabular}{|c|c|c|}
\hline Family history of thrombosis & 3 & $0(0 \%)$ \\
\hline Positive factor V Leiden & 3 & $0(0 \%)$ \\
\hline Positive prothrombin 20210A & 3 & $0(0 \%)$ \\
\hline Elevated serum homocysteine & 3 & $0(0 \%)$ \\
\hline Heparin-induced thrombocytopenia & 3 & $0(0 \%)$ \\
\hline Positive lupus anticoagilant & 3 & $0(0 \%)$ \\
\hline Elevated anti-cardiolipin antibodies & 3 & $0(0 \%)$ \\
\hline Other congenital or acquired thrombophilia: D-dimer $>\mathrm{ULN}^{\square}$ & 3 & $102(61 \%)$ \\
\hline Other congenital or acquired thrombophilia: D-dimer $>3 \mathrm{ULN}^{\square}$ & 3 & $15(9 \%)$ \\
\hline COVID-19 symptomatic $\square$ & 3 & $66(39 \%)$ \\
\hline Stroke $(<1$ month $)$ & 5 & $0(0 \%)$ \\
\hline Multiple trauma ( $<1$ month) & 5 & $0(0 \%)$ \\
\hline Elective major lower extremity arthroplasty & 5 & $0(0 \%)$ \\
\hline Hip, pelvis or leg fracture ( $<1$ month $)$ & 5 & $0(0 \%)$ \\
\hline Acute spinal cord injury, paralysis ( $<1$ month) & 5 & $0(0 \%)$ \\
\hline COVID-19 symptomatic with positive D-dfimer ${ }^{\square}$ & 5 & $102(61 \%)$ \\
\hline
\end{tabular}

${ }^{\dagger}$ Evaluated at discharge or after death

${ }^{\square}$ Evaluated within the modified versions of Caprini score

BMI - body mass index; COPD - chronic obstructive pulmonary disease; DVT - deep vein thrombosis; PE - pulmonary embolism; ULN - upper limit or normal 
medRxiv preprint doi: https://doi.org/10.1101/2020.06.22.20137075; this version posted June 23, 2020. The copyright holder for this preprint (which was not certified by peer review) is the author/funder, who has granted medRxiv a license to display the preprint in perpetuity.

It is made available under a CC-BY-NC-ND 4.0 International license .

Table II. The value of Caprini score according to the version and time of evaluation

\begin{tabular}{|l|c|c|c|}
\hline \multirow{2}{*}{ Version of Caprini score } & \multicolumn{2}{|c|}{ Time of evaluation } & \multirow{2}{*}{$\mathbf{p}_{\mathbf{1}}$} \\
\cline { 2 - 3 } & At admission & At discharge or death & \\
\hline Caprini[orig] & $5.4 \pm 1.8$ & $5.9 \pm 2.5$ & $<0.001$ \\
\hline Caprini[Dd>ULN] & $7.3 \pm 2.6$ & $7.7 \pm 3.3$ & $<0.001$ \\
\hline Caprini[Dd>3ULN] & $5.7 \pm 2.1$ & $6.1 \pm 2.9$ & $<0.001$ \\
\hline Caprini[COVID-19] & $9.6 \pm 2.3$ & $10.0 \pm 3.0$ & $<0.001$ \\
\hline $\mathrm{p}_{2}$ & $<0.001$ & $<0.001$ & \\
\hline
\end{tabular}

$\mathrm{p}_{1}$ - paried t-test; $\mathrm{p}_{2}$ - ANOVA

Caprini[orig] - the original score; Caprini[Dd $>\mathrm{ULN}]$ - considering 3 points if D-dimer increased over the ULN; Caprini[Dd>3ULN] - considering 3 points if D-dimer increased $>3$ times over ULN; Caprini[COVID-19] - considering 2 points for asymptomatic infection; 3 points for symptomatic infection; 5 points for symptomatic infection with positive D-dimer; ULN - upper limit of normal 
medRxiv preprint doi: https://doi.org/10.1101/2020.06.22.20137075; this version posted June 23, 2020. The copyright holder for this preprint (which was not certified by peer review) is the author/funder, who has granted medRxiv a license to display the preprint in perpetuity.

It is made available under a CC-BY-NC-ND 4.0 International license .

Table III. Predictability of different versions of Caprini score for symptomatic VTE and unfavorable outcome in COVID-19 patients by the single-factor logistic regression

\begin{tabular}{|l|c|c|c|}
\hline Version of Caprini score & OR & 95\% CI & p \\
\hline \multicolumn{5}{|c|}{ Symptomatic VTE } \\
\hline Caprini[orig:adm] & 1.87 & $1.34-2.61$ & $<0.001$ \\
\hline Caprini[Dd>ULN:adm] & 1.63 & $1.23-2.17$ & 0.001 \\
\hline Caprini[Dd>3ULN:adm] & 1.59 & $1.24-2.05$ & $<0.001$ \\
\hline Caprini[COVID-19:adm] & 1.73 & $1.27-2.34$ & $<0.001$ \\
\hline Caprini[orig:fin] & 1.73 & $1.36-2.20$ & $<0.001$ \\
\hline Caprini[Dd>ULN:fin] & 1.58 & $1.28-1.95$ & $<0.001$ \\
\hline Caprini[Dd>3ULN:fin] & 1.61 & $1.30-2.00$ & $<0.001$ \\
\hline Caprini[COVID-19:fin] & 1.63 & $1.31-2.03$ & $<0.001$ \\
\hline & Unfavorable outcome & $<0.001$ \\
\hline Caprini[orig:adm] & 1.84 & $1.43-2.38$ & $<0.001$ \\
\hline Caprini[Dd>ULN:adm] & 1.57 & $1.29-1.90$ & $<0.001$ \\
\hline Caprini[Dd>3ULN:adm] & 1.61 & $1.31-1.98$ & $<0.001$ \\
\hline Caprini[COVID-19:adm] & 1.68 & $1.35-2.10$ & $<010$ \\
\hline
\end{tabular}

Unfavorable outcome represents the combination of symptomatic VTE, admission to the ICU, requirement for mechanical ventilation, and death.

Caprini[orig:adm] - the original score assessed at admission; Caprini[orig:fin] - the original score assessed at discharge or death; Caprini[Dd>ULN:adm] - considering 3 points if Ddimer increased over ULN, score assessed at admission; Caprini[Dd>ULN:fin] - considering 3 points if D-dimer increased over ULN, score assessed at discharge or death; Caprini[Dd>3ULN:adm] - considering 3 points if D-dimer increased $>3$ times over ULN, score assessed at admission; Caprini[Dd>3ULN:fin] - considering 3 points if D-dimer increased >3 times over ULN, score assessed at discharge or death; Caprini[COVID-19:adm] - considering 2 points for asymptomatic infection, 3 points for symptomatic infection, 5 points for symptomatic infection with positive D-dimer, score assessed at admission; Caprini[COVID-19:fin] - considering 2 points for asymptomatic infection, 3 points for symptomatic infection, 5 points for symptomatic infection with positive D-dimer, score assessed at discharge or death; CI - confidence interval; OR - odds ratio; VTE - venous thromboembolism; ULN - upper limit of normal 
medRxiv preprint doi: https://doi.org/10.1101/2020.06.22.20137075; this version posted June 23, 2020. The copyright holder for this preprint (which was not certified by peer review) is the author/funder, who has granted medRxiv a license to display the preprint in perpetuity.

It is made available under a CC-BY-NC-ND 4.0 International license .

Table IV. Predictability of different versions of Caprini score for symptomatic VTE and unfavorable outcome in COVID-19 patients by the analysis of ROC curve

\begin{tabular}{|l|c|c|c|c|c|}
\hline Version of Caprini score & AUC \pm SD & p & Cut-off & Sensitivity & Specificity \\
\hline \multicolumn{5}{|c|}{ Symptomatic VTE } \\
\hline Caprini[orig:adm] & $0.769 \pm 0.090$ & 0.003 & 7 & $73 \%$ & $80 \%$ \\
\hline Caprini[Dd>ULN:adm] & $0.776 \pm 0.096$ & 0.002 & 10 & $73 \%$ & $85 \%$ \\
\hline Caprini[Dd>3ULN:adm] & $0.757 \pm 0.090$ & 0.004 & 7 & $73 \%$ & $76 \%$ \\
\hline Caprini[COVID-19:adm] & $0.772 \pm 0.097$ & 0.003 & 12 & $73 \%$ & $84 \%$ \\
\hline Caprini[orig:fin] & $0.803 \pm 0.095$ & 0.001 & 11 & $73 \%$ & $96 \%$ \\
\hline Caprini[Dd>ULN:fin] & $0.801 \pm 0.100$ & 0.001 & 14 & $73 \%$ & $97 \%$ \\
\hline Caprini[Dd>3ULN:fin] & $0.797 \pm 0.096$ & 0.001 & 11 & $73 \%$ & $94 \%$ \\
\hline Caprini[COVID-19:fin] & $0.799 \pm 0.100$ & 0.001 & 16 & $73 \%$ & $97 \%$ \\
\hline & Unfavorable outcome & & \\
\hline Caprini[orig:adm] & $0.775 \pm 0.046$ & $<0.001$ & 6 & $74 \%$ & $66 \%$ \\
\hline Caprini[Dd>ULN:adm] & $0.775 \pm 0.049$ & $<0.001$ & 9 & $68 \%$ & $75 \%$ \\
\hline Caprini[Dd>3ULN:adm] & $0.778 \pm 0.046$ & $<0.001$ & 6 & $77 \%$ & $63 \%$ \\
\hline Caprini[COVID-19:adm] & $0.780 \pm 0.048$ & $<0.001$ & 11 & $68 \%$ & $75 \%$ \\
\hline
\end{tabular}

Unfavorable outcome represents the combination of symptomatic VTE, admission to the ICU, requirement for mechanical ventilation, and death.

AUC - area under the curve; Caprini[orig:adm] - the original score assessed at admission; Caprini[orig:fin] - the original score assessed at discharge or death; Caprini[Dd>ULN:adm] considering 3 points if D-dimer increased over ULN, score assessed at admission; Caprini[Dd>ULN:fin] - considering 3 points if D-dimer increased over ULN, score assessed at discharge or death; Caprini[Dd>3ULN:adm] - considering 3 points if D-dimer increased $>3$ times over ULN, score assessed at admission; Caprini[Dd>3ULN:fin] - considering 3 points if D-dimer increased $>3$ times over ULN, score assessed at discharge or death; Caprini[COVID-19:adm] - considering 2 points for asymptomatic infection, 3 points for symptomatic infection, 5 points for symptomatic infection with positive D-dimer, score assessed at admission; Caprini[COVID-19:fin] - considering 2 points for asymptomatic infection, 3 points for symptomatic infection, 5 points for symptomatic infection with positive D-dimer, score assessed at discharge or death; ROC - receiver operating characteristic; SD - standard deviation; VTE - venous thromboembolism; ULN - upper limit of normal 
medRxiv preprint doi: https://doi.org/10.1101/2020.06.22.20137075; this version posted June 23, 2020. The copyright holder for this preprint (which was not certified by peer review) is the author/funder, who has granted medRxiv a license to display the preprint in perpetuity.

\author{
It is made available under a CC-BY-NC-ND 4.0 International license.
}


medRxiv preprint doi: https://doi.org/10.1101/2020.06.22.20137075; this version posted June 23, 2020. The copyright holder for this preprint (which was not certified by peer review) is the author/funder, who has granted medRxiv a license to display the preprint in perpetuity.

It is made available under a CC-BY-NC-ND 4.0 International license .

Figure 1. The incidence of VTE according to the different modifications of Caprini score assessed at the time of admission

Caprini[orig:adm] - the original score assessed at admission ( $\mathrm{p}<0.001$ by GLM);

Caprini[Dd>ULN:adm] - considering 3 points if D-dimer increased over ULN, score assessed at admission ( $\mathrm{p}<0.001$ by GLM);

Caprini[Dd>3ULN:adm] - considering 3 points if D-dimer increased $>3$ times over ULN, score assessed at admission ( $\mathrm{p}<0.001$ by GLM);

Caprini[COVID-19:adm] - considering 2 points for asymptomatic infection, 3 points for symptomatic infection, 5 points for symptomatic infection with positive D-dimer, score assessed at admission ( $\mathrm{p}<0.001$ by GLM);

VTE - venous thromboembolism; ULN - upper limit of normal

Figure 2. The incidence of symptomatic VTE according to the different modifications of Caprini score assessed at the time of discharge or death

Caprini[orig:fin] - the original score assessed at discharge or death ( $\mathrm{p}<0.001$ by GLM);

Caprini[Dd>ULN:fin] - considering 3 points if D-dimer increased over ULN, score assessed at discharge or death ( $\mathrm{p}<0.001$ by GLM);

Caprini[Dd>3ULN:fin] - considering 3 points if D-dimer increased $>3$ times over ULN, score assessed at discharge or death ( $\mathrm{p}<0.001$ by GLM);

Caprini[COVID-19:fin] - considering 2 points for asymptomatic infection, 3 points for symptomatic infection, 5 points for symptomatic infection with positive D-dimer, score assessed at discharge or death ( $\mathrm{p}<0.001$ by GLM);

VTE - venous thromboembolism; ULN - upper limit of normal

Figure 3. The incidence of unfavorable outcome according to the different modifications of Caprini score assessed at the time of admission

Unfavorable outcome combined symptomatic VTE, admission to the intensive care unit, the requirement for mechanical ventilation and death

Caprini[orig:adm] - the original score assessed at admission ( $\mathrm{p}<0.001$ by GLM);

Caprini[Dd>ULN:adm] - considering 3 points if D-dimer increased over ULN, score assessed at admission ( $\mathrm{p}<0.001$ by GLM);

Caprini[Dd>3ULN:adm] - considering 3 points if D-dimer increased >3 times over ULN, score assessed at admission ( $\mathrm{p}<0.001$ by GLM); 
medRxiv preprint doi: https://doi.org/10.1101/2020.06.22.20137075; this version posted June 23, 2020. The copyright holder for this preprint (which was not certified by peer review) is the author/funder, who has granted medRxiv a license to display the preprint in perpetuity.

It is made available under a CC-BY-NC-ND 4.0 International license .

Caprini[COVID-19:adm] - considering 2 points for asymptomatic infection, 3 points for symptomatic infection, 5 points for symptomatic infection with positive D-dimer, score assessed at admission ( $\mathrm{p}<0.001$ by GLM);

ULN - upper limit of normal

Figure 4. Predictability of different versions of Caprini score for symptomatic VTE by the ROC curves

Caprini[orig:adm] - the original score assessed at admission; Caprini[orig:fin] - the original score assessed at discharge or death; Caprini[Dd>ULN:adm] - considering 3 points if Ddimer increased over ULN, score assessed at admission; Caprini[Dd>ULN:fin] - considering 3 points if D-dimer increased over ULN, score assessed at discharge or death; Caprini[Dd>3ULN:adm] - considering 3 points if D-dimer increased $>3$ times over ULN, score assessed at admission; Caprini[Dd>3ULN:fin] - considering 3 points if D-dimer increased >3 times over ULN, score assessed at discharge or death; Caprini[COVID-19:adm] - considering 2 points for asymptomatic infection, 3 points for symptomatic infection, 5 points for symptomatic infection with positive D-dimer, score assessed at admission; Caprini[COVID-19:fin] - considering 2 points for asymptomatic infection, 3 points for symptomatic infection, 5 points for symptomatic infection with positive D-dimer, score assessed at discharge or death; $\mathrm{ROC}$ - receiver operating characteristic

Figure 5. Predictability of different versions of Caprini score for unfavorable outcome in COVID-19 by the ROC curves

Unfavorable outcome combined symptomatic VTE, admission to the intensive care unit, the requirement for mechanical ventilation and death

Caprini[orig:adm] - the original score assessed at admission; Caprini[Dd $>$ ULN:adm] considering 3 points if D-dimer increased over ULN, score assessed at admission; Caprini[Dd>3ULN:adm] - considering 3 points if D-dimer increased $>3$ times over ULN, score assessed at admission; Caprini[COVID-19:adm] - considering 2 points for asymptomatic infection, 3 points for symptomatic infection, 5 points for symptomatic infection with positive D-dimer, score assessed at admission; ROC - receiver operating characteristic 
medRxiv preprint doi: https://doi.org/10.1101/2020.06.22.20137075; this version posted June 23, 2020. The copyright holder for this preprint (which was not certified by peer review) is the author/funder, who has granted medRxiv a license to display the preprint in perpetuity. It is made available under a CC-BY-NC-ND 4.0 International license .

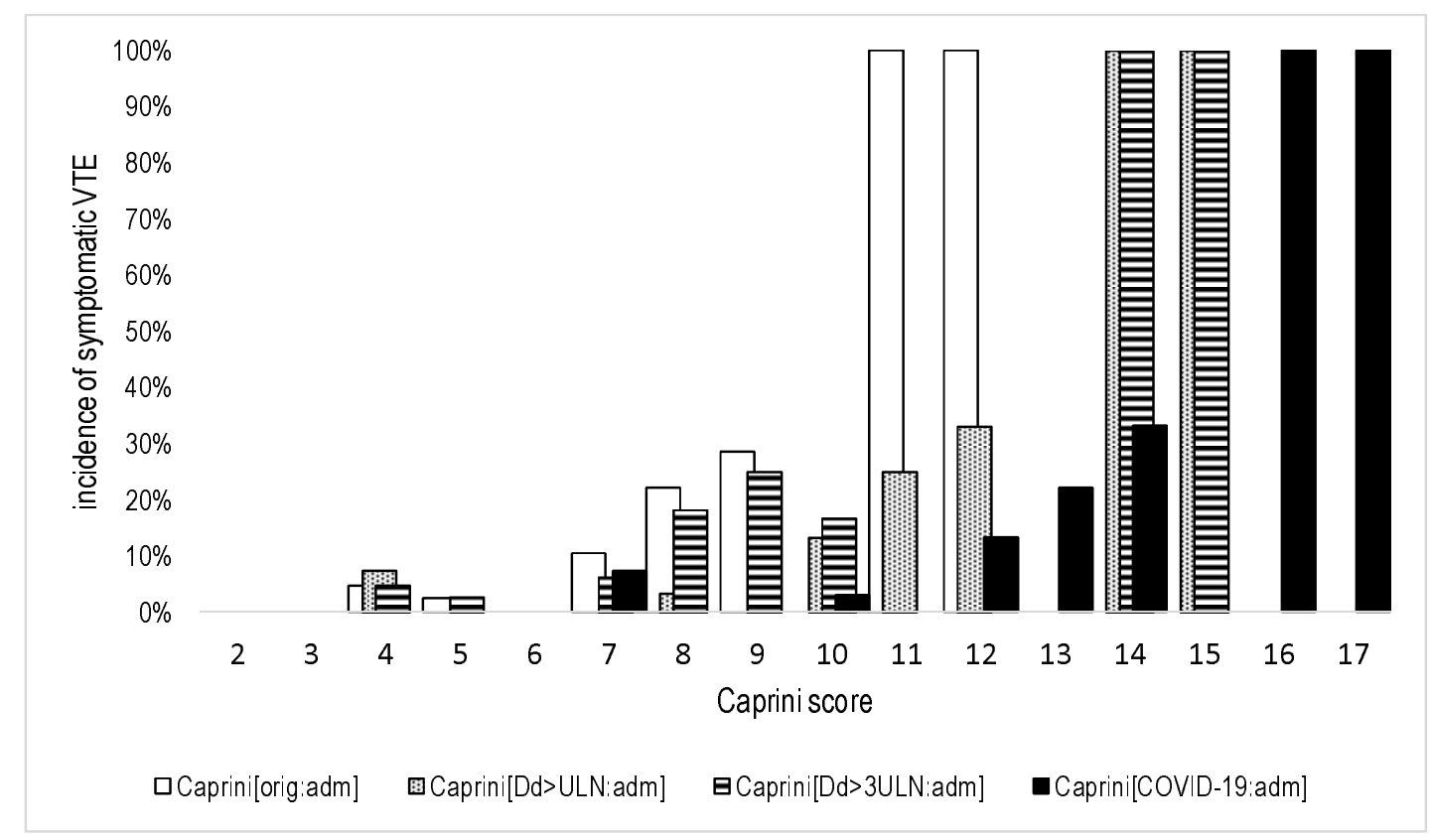


medRxiv preprint doi: https://doi.org/10.1101/2020.06.22.20137075; this version posted June 23, 2020. The copyright holder for this preprint (which was not certified by peer review) is the author/funder, who has granted medRxiv a license to display the preprint in perpetuity. It is made available under a CC-BY-NC-ND 4.0 International license .

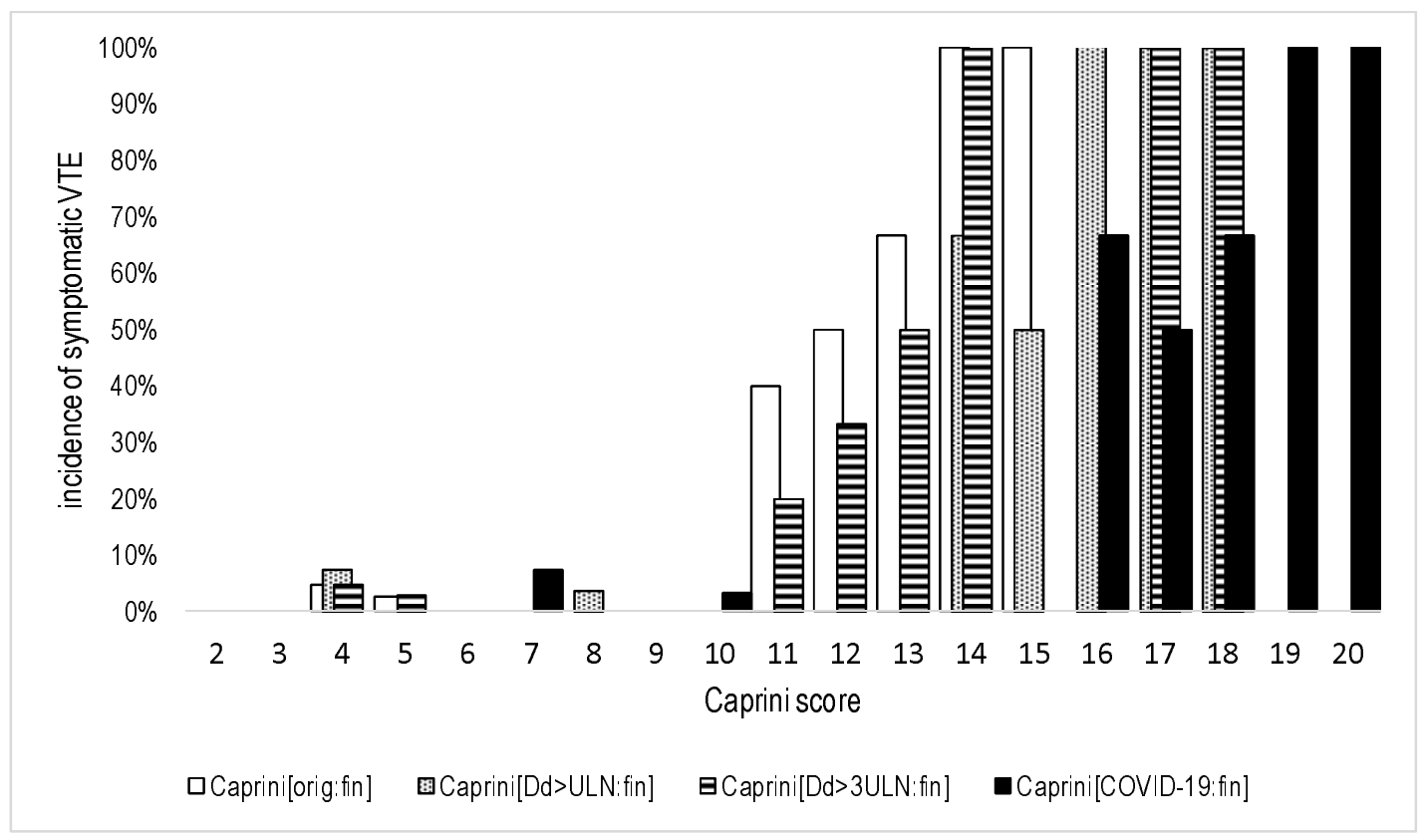


medRxiv preprint doi: https://doi.org/10.1101/2020.06.22.20137075; this version posted June 23, 2020. The copyright holder for this preprint (which was not certified by peer review) is the author/funder, who has granted medRxiv a license to display the preprint in perpetuity.

It is made available under a CC-BY-NC-ND 4.0 International license .

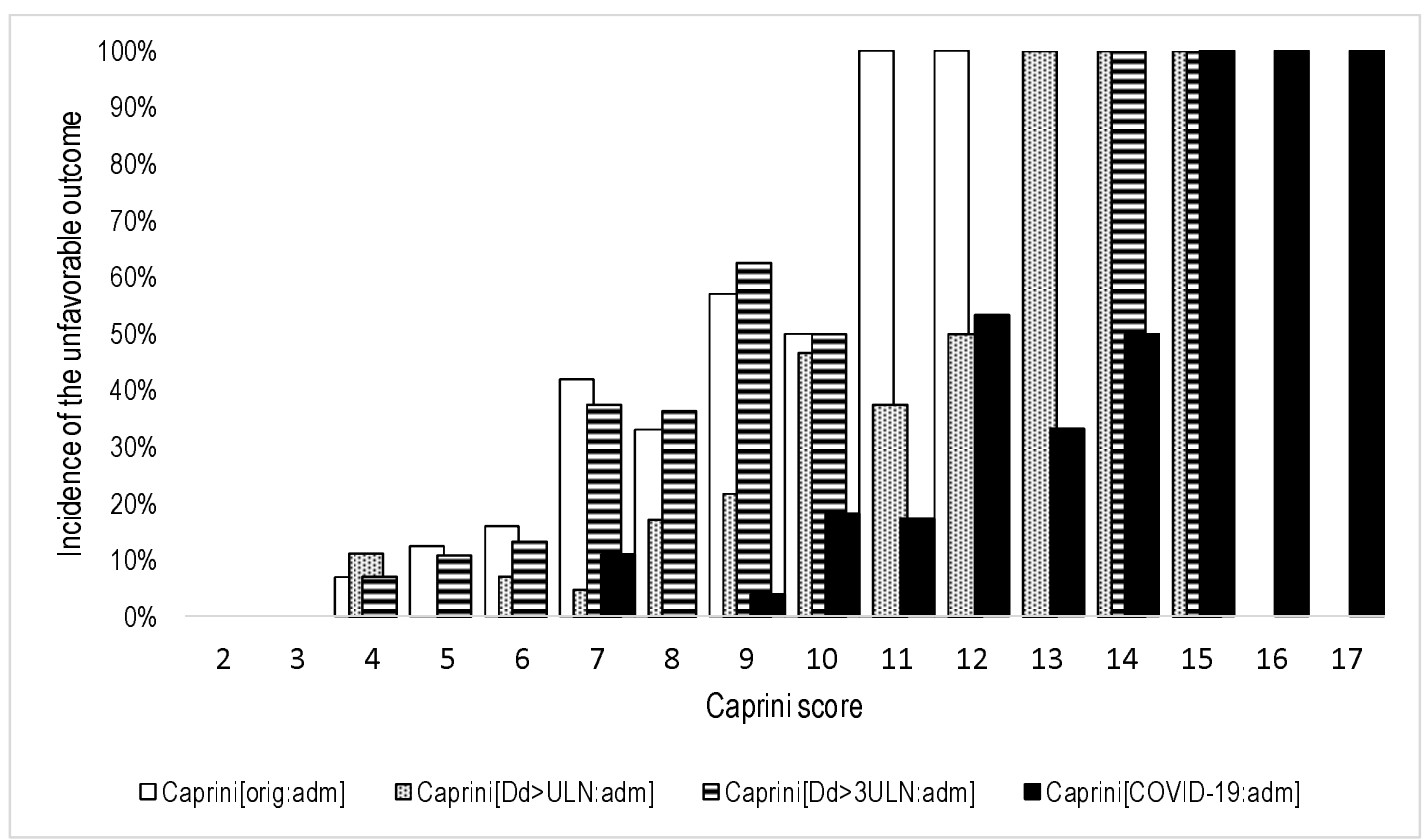




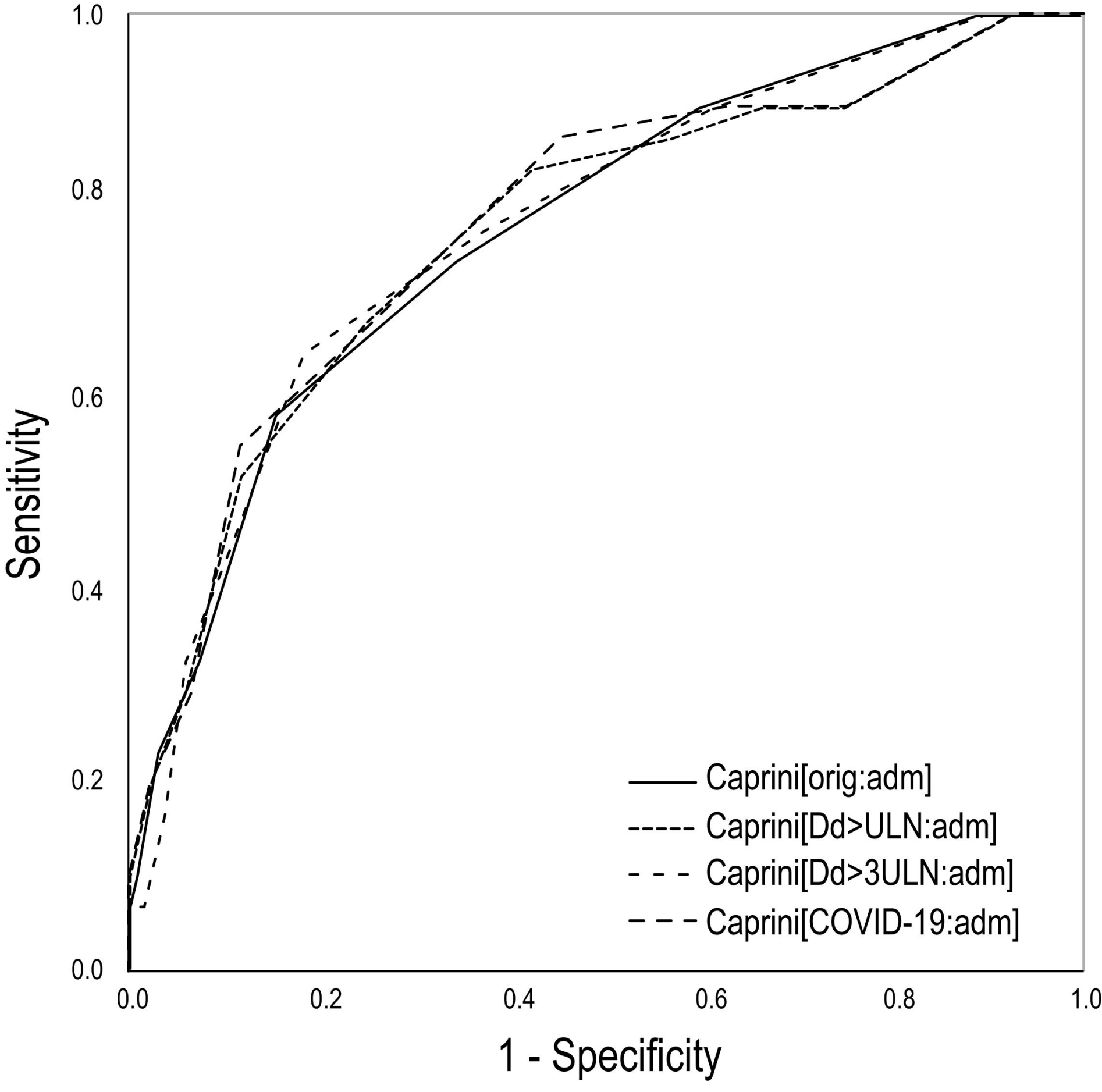

